\title{
Reconnaissance of Hydrologic Monitoring Sites and Preliminary Monitoring Plan for the Vale, Oregon, Geothermal Area
}

U.S. Geological Survey

Open-File Report 95-384

\section{Prepared in cooperation with}

BONNEVILLE POWER ADMINISTRATION

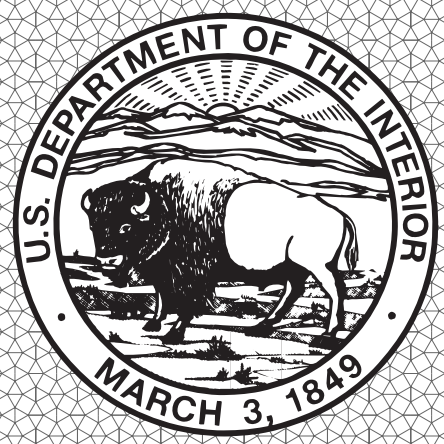


Reconnaissance of Hydrologic Monitoring Sites and Preliminary Monitoring Plan for the Vale, Oregon, Geothermal Area

By MARSHALL W. GANNETT and RODNEY R. CALDWELL

U.S. Geological Survey

Open-File Report 95-384

Prepared in cooperation with the

BONNEVILLE POWER ADMINISTRATION

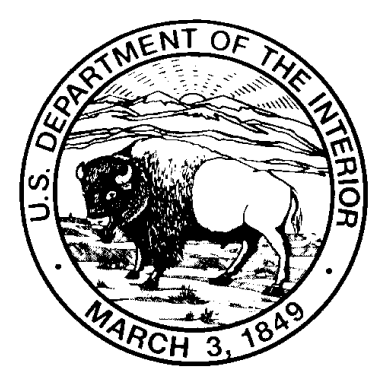

Portland, Oregon

1996 


\title{
U. S. DEPARTMENT OF THE INTERIOR BRUCE BABBITT, Secretary
}

\author{
U.S. GEOLOGICAL SURVEY \\ Gordon P. Eaton, Director
}

The use of trade, product, or firm names in this publication is for descriptive purposes only and does not imply endorsement by the U.S. Government.

For additional information

write to:

District Chief

U.S. Geological Survey, WRD 10615 S.E. Cherry Blossom Drive

Portland, OR 97216
Copies of this report can be purchased from:

U.S. Geological Survey

Branch of Information Services

Box 25286, Federal Center

Denver, CO 80225 


\section{CONTENTS}

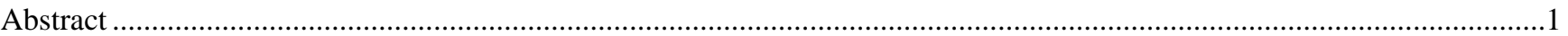

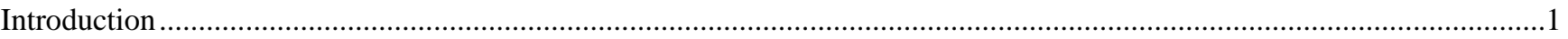

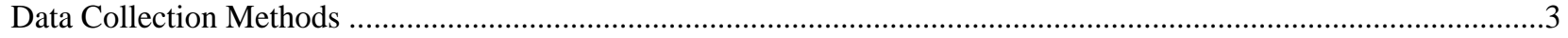

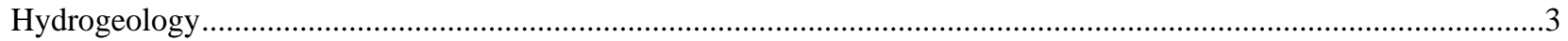

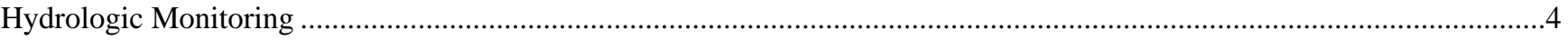

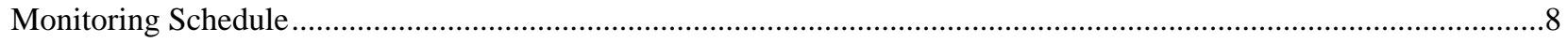

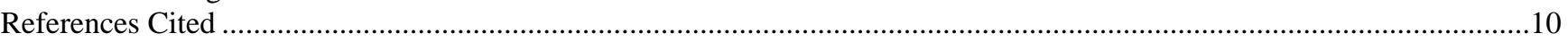

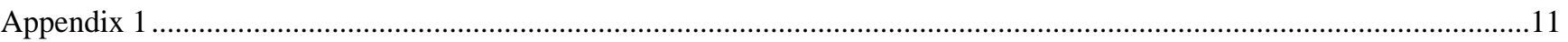

Figure

1. Location of the Vale, Oregon, Known Geothermal Resource Area; approximate location of the Willow Creek fault and associated heat-flow anomaly; generalized ground-water level contours; and proposed monitoring sites....

\section{Tables}

1. Description of and preliminary data from proposed monitoring sites in the vicinity of the

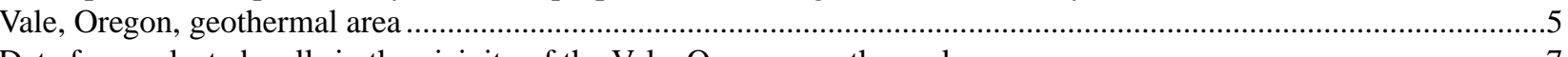

2. Data from selected wells in the vicinity of the Vale, Oregon, geothermal area ........................................................

3. Data from selected springs in the vicinity of the Vale, Oregon, geothermal area .................................................. 8

4. Measurement and sampling schedule for monitoring in the Vale, Oregon, geothermal area .......................................

\section{CONVERSION FACTORS AND VERTICAL DATUM}

\begin{tabular}{|c|c|c|}
\hline Multiply & By & To obtain \\
\hline \multicolumn{3}{|c|}{ Length } \\
\hline inch & 25.4 & millimeter \\
\hline foot & 0.3048 & meter \\
\hline mile & 1.609 & kilometer \\
\hline \multicolumn{3}{|c|}{ Area } \\
\hline acre & 4,047 & square meter \\
\hline acre & d 0.4047 & hectare \\
\hline square mile & 259.0 & hectare \\
\hline square mile & 2.590 & square kilometer \\
\hline \multicolumn{3}{|c|}{ Flow } \\
\hline cubic foot per second & 0.02832 & cubic meter per second \\
\hline gallon per minute & 0.06309 & liter per second \\
\hline gallon per minute & 0.002228 & cubic foot per second \\
\hline \multicolumn{3}{|c|}{ Temperature } \\
\hline degrees Fahrenheit $\left({ }^{\circ} \mathrm{F}\right)$ & $\left({ }^{\circ} \mathrm{F}-32\right) / 1.8={ }^{\circ} \mathrm{C}$ & degrees Celsius $\left({ }^{\circ} \mathrm{C}\right)$ \\
\hline
\end{tabular}




\section{WELL-NUMBERING SYSTEM}

The well- and spring-numbering system used in this report is based on the rectangular system for subdivision of land. Each well "number" indicates the location of the well with respect to township, range, and section. Well 18S/45E-32aca is in T.18 S., R.45 E., sec. 32. Townships shown in this region are numbered south and east of the Willamette Baseline and Meridian (for example 18S/45E). The letters show the location within the section; the first letter (a) identifies the quarter section (160 acres); the second letter (c) identifies the quarter-quarter section (40 acres); and the third letter (a) identifies the quarter-quarter-quarter section (10 acres). Well 32aca is in the NE quarter of the SW quarter of the NE quarter of section 32, township 18 south, range 45 east (see figure below).

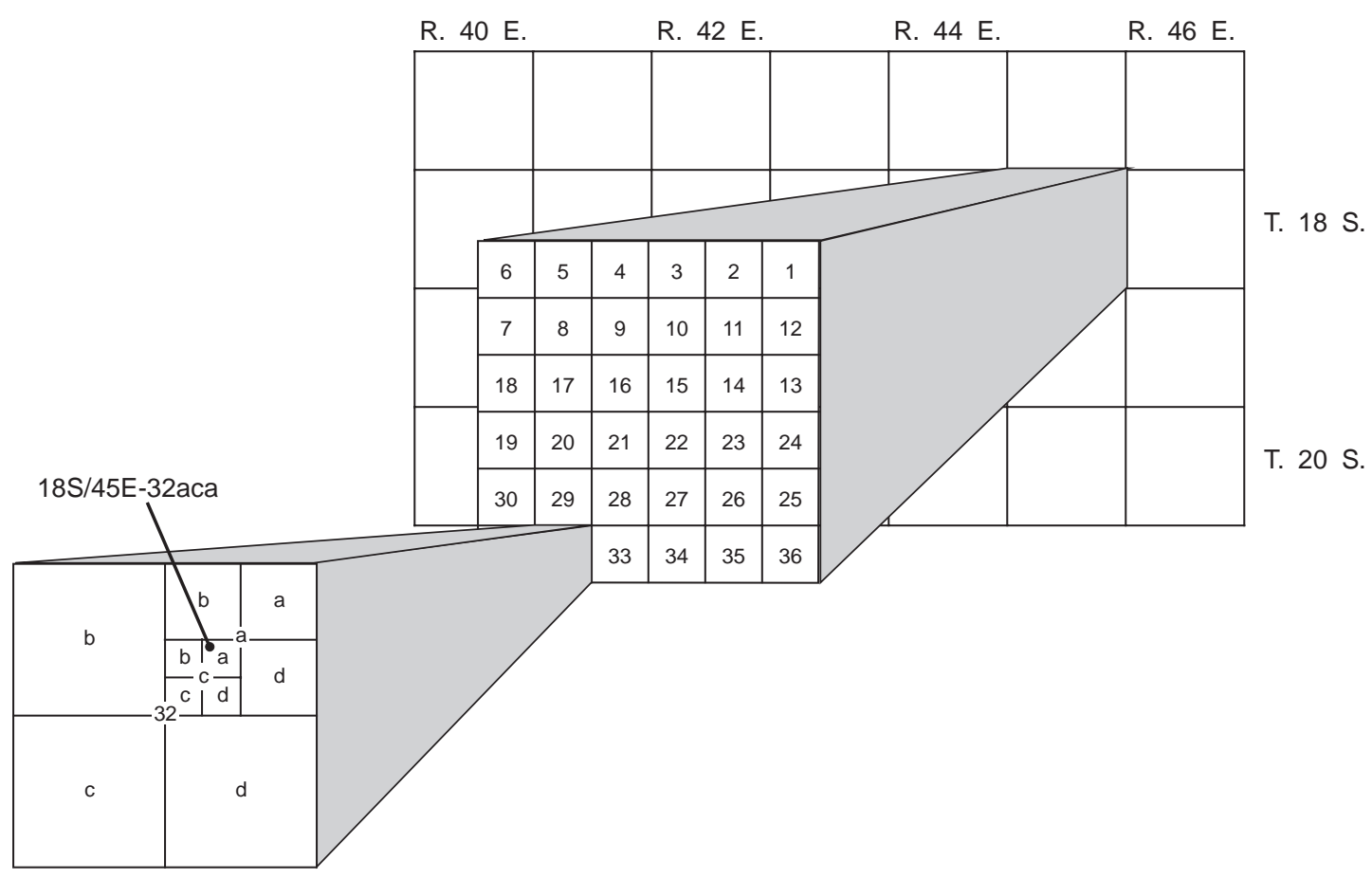




\title{
Reconnaissance of Hydrologic Monitoring Sites and Preliminary Monitoring Plan for the Vale, Oregon, Geothermal Area
}

\author{
By Marshall W. Gannett and Rodney R. Caldwell
}

\section{Abstract}

The Bonneville Power Administration is working with private industry to develop a geothermal demonstration project in the Known Geothermal Resources Area (KGRA) near Vale, Oregon. Hydrologic monitoring in the area is planned in order to evaluate any impacts from the proposed development. The hydrology in and around the Vale KGRA is not well known. Additionally, little is known about the targeted geothermal reservoir and the nature of its connection to the shallow ground-water system. Given this uncertainty, a variety of features were selected to ensure adequate monitoring coverage. Wells and springs in and around the geothermal area were evaluated, and 19 were selected as potential monitoring sites. In selecting wells and springs for monitoring, particular emphasis was placed on those with a known or probable connection with the geothermal system because they would most likely be the first to show any effects from development. The selected features include thermal wells in the hot-spring area near the town of Vale and a hot spring south of the KGRA. Several warm wells $\left(70\right.$ to $90^{\circ} \mathrm{F}$ ) near the KGRA were also selected because it is likely that the water produced from these wells includes a component of geothermal water. In order to identify any effects of development, it is necessary to have an understanding of natural and man-caused variations and trends prior to development. A quarterly measurement schedule is proposed to help characterize these variations and trends. It is anticipated that the proposed monitoring plan will be modified as exploration and development proceed and more is learned about the geothermal system.

\section{INTRODUCTION}

In order to evaluate the practicality and economic viability of geothermal resources as an energy source for the Pacific Northwest, the Bonneville Power Administration is participating with private industry in developing a number of geothermal demonstration projects in Oregon. To assess the environmental impacts of geothermal development and to ensure that the proposed development proceeds in an environmentally responsible manner, environmental monitoring (including hydrologic monitoring) is either being conducted or is planned at each of the sites prior to development. Collection of predevelopment baseline data and monitoring data during exploration and development at the proposed demonstration projects will allow regulatory agencies to recognize and assess any effects of development, as well as the effects of any mitigation efforts.

The Known Geothermal Resources Area (KGRA) near Vale, Oregon, is one of the sites in the State selected for a demonstration project. The Vale geothermal area is in Malheur County in the far eastern part of Oregon, about 10 to 15 miles from the Oregon-Idaho border (fig. 1). The KGRA encompasses 36 square miles and includes a northwest-trending area of elevated crustal heat flow approximately 10 miles long and 2 miles wide (Blackwell and others, 1978). An area of hot springs occurs at the northern end of the heat flow anomaly immediately east of Vale (fig. 1). The maximum reported temperature at the hot springs is $194^{\circ} \mathrm{F}$. This hot-spring area is the only natural hydrologic surface manifestation of the geothermal system in the KGRA; however, additional hot springs occur to the south of the KGRA. A shallow thermal aquifer that underlies an area of several acres near the Vale hot springs has been developed for a variety of uses, including domestic heating, grain drying, mushroom growing, and as a source of hot water for a slaughterhouse. 


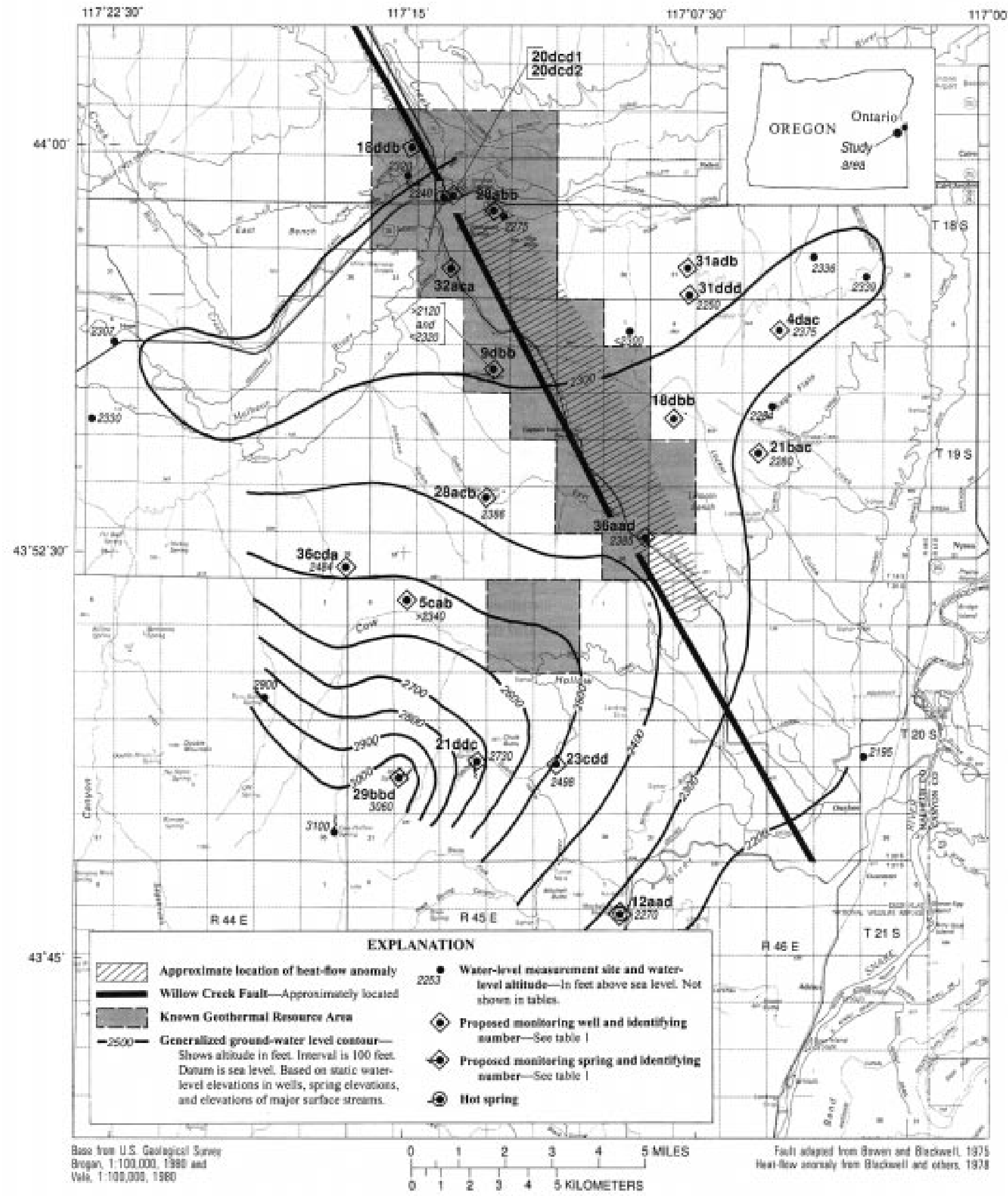

Figure 1. Location of the Vale, Oregon, Known Geothermal Resource Area; approximate location of the Willow Creek fault and associated heat-flow anomaly; generalized ground-water level contours; and proposed monitoring sites. 
Production temperatures in wells in this aquifer are as high as $223^{\circ} \mathrm{F}$ (Gannett, 1988). The hot springs and the adjacent shallow thermal aquifer are thought to represent outflow from a deeper, and presumably hotter, geothermal system. The presence of such a system is suggested by chemical geothermometry, which indicates reservoir temperatures in excess of $300^{\circ} \mathrm{F}$ (Brown and others, 1980; Gannett, 1988), and by the size of the heat-flow anomaly. This deeper system is the target of proposed exploration and development.

The purpose for hydrologic monitoring in the vicinity of the Vale geothermal area is to detect any effects of geothermal development should they occur. In order to recognize such effects, the magnitude of preexisting or background variations in the hydrologic system must be known. Therefore, sufficient monitoring should take place prior to development to allow characterization of the preexisting variations and trends.

The purpose of this report is to describe the hydrologic features in and around the Vale KGRA suitable for hydrologic monitoring, describe the methodology used to select those features, report preliminary data collected during the process of locating the features, and present a preliminary monitoring program.

The project scope included a review of the literature on the Vale geothermal area, compilation of existing hydrologic information (particularly ground-water information), and 2 weeks of field reconnaissance to locate features that may serve as monitoring sites (in order to assess site suitability and collect preliminary data). This information was used to develop a preliminary hydrologic monitoring plan for the Vale geothermal area. The monitoring program will likely be refined as exploration and development proceed and more information on the geology and hydrology of the area becomes available. Additionally, as geothermal operations develop and other activities are planned, such as pumping of nonthermal water for cooling and reinjection of cooling water or geothermal effluent, additional monitoring will likely be required.

\section{Data Collection Methods}

Springs and wells were plotted on 1:24,000-scale topographic maps, and their locations are reported by township, range, section, and 10-acre subdivision within a section. The locations of some features were determined using a global positioning system (GPS) receiver with an accuracy of about 100 feet. Water levels were measured with either steel surveyor's tapes or calibrated electric tapes. Specific conductances were measured with an Orion conductivity meter that was calibrated to standard solutions. Temperatures were measured with either a mercury thermometer or a digital electronic thermometer. Information on field-located wells and springs was entered into the U.S. Geological Survey National Water Information System.

\section{Hydrogeology}

The Vale geothermal area lies near the western margin of the Snake River Plain geologic province near its boundary with the Owyhee uplands. The geology of the Vale geothermal area is dominated by fine-grained sedimentary rocks deposited in a lake that occupied part of the western Snake River Plain during the Pliocene epoch (Brown, 1982; Ferns and Urbanczyk, 1990; Gannett, 1990). These rocks are underlain by basalt at a depth of approximately 650 feet beneath the Vale area (Brown, 1982); the depth increases to 1,000 feet in the southern part of the KGRA (Ferns and Urbanczyk, 1990). The geothermal area encompasses a series of normal faults that are part of a larger fault zone that extends at least 30 miles from the area of Adrian, Oregon, northwest through the geothermal area and up the Willow Creek Valley 20 miles northwest of Vale. Bowen and Blackwell (1975) refer to the main fault along this trend as the Willow Creek Fault (fig. 1). Blackwell and others (1978) show that the heat flow anomaly in the Vale area is coincident with the Willow Creek Fault, which suggests that the fault may provide a conduit for upward flow of thermal water.

Little information is available on the regional hydrogeology in the Vale area. A contour map showing a generalized water-level surface drawn from water-level elevations in wells and springs (fig. 1) indicates that ground water in the area of the KGRA flows north and east toward the Malheur and Snake Rivers from topographically high areas between the two rivers. This suggests that shallow thermal water flows northeastward from the Willow Creek Fault. 
That hypothesis is supported by the presence of several wells that produce warm water $\left(70\right.$ to $\left.80^{\circ} \mathrm{F}\right)$ to the east of the fault zone. The general lack of wells and well temperature data to the west of the fault zone, however, make this observation inconclusive. Most of the wells shown in figure 1 are completed in either lacustrine sedimentary rock or alluvium.

\section{HYDROLOGIC MONITORING}

Selection of potential monitoring sites was based on a careful review of information on wells and springs in and around the KGRA. Sources of information included published geologic reports and maps, topographic maps (with spring locations), Oregon water-well reports (well logs), and project files in the Bureau of Land Management (BLM) office in Vale. Candidate sites were visited in the field during the summer of 1992, and their suitability for long-term monitoring was determined on the basis of characteristics such as access, existence of pumps for sampling (wells only), possibility of obtaining accurate flow measurements (springs only), and representativeness.

The Vale KGRA includes both developed and undeveloped land. The northern one-third includes the city of Vale and the surrounding farmland. The southern two-thirds consists largely of rangeland managed by the BLM. Most of the wells available for monitoring are located in the northern part of the KGRA. The southern two-thirds of the KGRA has few suitable monitoring sites.

The nature of the hydrothermal system at Vale and its relationship to the surrounding regional and local ground-water flow systems are largely unknown. In light of this general lack of understanding, it was considered prudent to monitor a variety of features, both thermal and nonthermal. Because any effects of geothermal development are most likely to be seen first in the geothermal system itself, particular attention was focused on wells and springs with known or apparent close connections to the geothermal system. A list of proposed monitoring sites and preliminary field data are shown in table 1 . The locations of the proposed sites are shown in figure 1. The main objective during this reconnaissance field work was to locate features and determine their suitability for monitoring purposes; few field data and no water samples were collected. Additional information on selected wells and springs is presented in tables 2 and 3 , respectively.

The only opportunities in the KGRA for directly monitoring geothermal fluids are in the hot-spring area east of Vale. Until the mid 1980's, hot water discharged from a series of small springs along the bank of the Malheur River. The hot springs no longer flow above river level, and the only natural discharge is presently from the banks below river level. Gannett (1988) attributed the decrease in hot-spring discharge and temperature to head losses caused by pumping of thermal water from the adjacent shallow aquifer. Existing geothermal test wells and production wells in the hot-spring area (table 2) now provide the best opportunities for sampling geothermal water and measuring temperature and water levels. Should the flow of thermal water to the shallow thermal water in the hot-spring area from the deep geothermal system be effected by development, temperatures and pressures in wells in the hot-spring area would respond accordingly. Monitoring wells in the hot-spring area would provide a qualitative check on flow to the hot-spring area, but only if pumping of water from the shallow thermal aquifer in the hot-spring area is carefully monitored also.

Monitoring the total discharge of thermal fluids from the geothermal system at Vale would be desirable; however, such measurement would be problematic because much of the discharge occurs directly to the stream. Measuring the flux of a conservative component of the geothermal water, such as chloride, into the Malheur River may provide an estimate of the total thermal water flow from the hot-spring area. This technique has been used in other geothermal areas in the Western United States, including several locations in the Oregon Cascade Range (Ingebritsen and others, 1989), Yellowstone (Norton and Friedman, 1985), and Long Valley California (Farrar and others, 1985). In the Vale geothermal area, estimation of the chloride flux would be accomplished by measuring the streamflow and chloride concentrations in the river upstream and downstream of the hot-spring area and in Willow Creek, which enters the Malheur River at the hotspring area. Testing the feasibility of this technique was beyond the scope of this reconnaissance study but would be informative. 
Table 1. Description of and preliminary data from proposed monitoring sites in the vicinity of the Vale, Oregon, geothermal area

$\left[{ }^{\circ} \mathrm{F}\right.$, degrees Fahrenheit; $\mu / \mathrm{cm}$, microsiemens per centimeter at $25^{\circ}$ Celsius; psi, pounds per square inch; --, no data;

KGRA, Known Geothermal Resource Area; BLM, Bureau of Land Management; >, greater than; NA, not applicable]

\begin{tabular}{|c|c|c|c|c|c|c|}
\hline Location & Name of Feature & Description & $\begin{array}{l}\text { Temperature } \\
\left({ }^{\circ} \mathrm{F}\right)\end{array}$ & $\begin{array}{c}\text { Specific } \\
\text { conductance } \\
(\mu / \mathrm{cm})\end{array}$ & $\begin{array}{l}\text { Depth } \\
\text { of well } \\
\text { (feet) }\end{array}$ & $\begin{array}{l}\text { Depth to } \\
\text { water (feet } \\
\text { below land } \\
\text { surface) }\end{array}$ \\
\hline $18 \mathrm{~S} / 45 \mathrm{E} 18 \mathrm{ddb}$ & Charles Burden Well & $\begin{array}{l}\text { Domestic well } 1 \text { mile } \\
\text { north of Vale }\end{array}$ & 71 & 909 & 260 & $1_{33}$ \\
\hline $18 \mathrm{~S} / 45 \mathrm{E} 20 \mathrm{dcd} 1$ & $\begin{array}{l}\text { Oregon Trail Mushroom } \\
\text { Company Production } \\
\text { Well (Hammond Well 1) }\end{array}$ & $\begin{array}{l}\text { Geothermal well in the } \\
\text { Vale hot-spring area }\end{array}$ & $\begin{array}{l}223 \\
\text { (in } 76 \mathrm{psi} \\
\text { discharge line) }\end{array}$ & 1,750 & 125 & -- \\
\hline $18 \mathrm{~S} / 45 \mathrm{E} 20 \mathrm{dcd} 2$ & $\begin{array}{l}\text { Robert Butler } \\
\text { Geothermal Test } \\
\text { Well } 2\end{array}$ & $\begin{array}{l}\text { Unused geothermal } \\
\text { test well in the Vale } \\
\text { hot-spring area. }\end{array}$ & ${ }^{2} 229$ & -- & 140 & 22.87 \\
\hline $18 \mathrm{~S} / 45 \mathrm{E} 28 \mathrm{abb}$ & Robert Butler Well & $\begin{array}{l}\text { Domestic well } 1 \text { mile east } \\
\text { of the Vale hot-spring area }\end{array}$ & 98.3 & 1,500 & 265 & ${ }^{1} 45$ \\
\hline $18 \mathrm{~S} / 45 \mathrm{E} 32 \mathrm{aca}$ & James Linville Well & $\begin{array}{l}\text { Domestic well } 1 \text { mile } \\
\text { south of Vale }\end{array}$ & 78 & 1,515 & 213 & ${ }^{1} 155$ \\
\hline $18 \mathrm{~S} / 46 \mathrm{E} 31 \mathrm{adb}$ & Betty Wendt Well & $\begin{array}{l}\text { Irrigation well } 2 \text { miles east } \\
\text { of the KGRA }\end{array}$ & 90 & 1,233 & 887 & ${ }^{1} 200$ \\
\hline 18S/46E 31ddd & Betty Wendt Well & $\begin{array}{l}\text { Unused irrigation well } \\
2 \text { miles east of the Vale } \\
\text { KGRA }\end{array}$ & 176 & -- & 757 & $1_{355}$ \\
\hline 19S/44E $36 \mathrm{cda}$ & Russell Land Co. Well & $\begin{array}{l}\text { Stock well } 3 \text { miles west of } \\
\text { the KGRA. One of few } \\
\text { wells in the area }\end{array}$ & -- & -- & 400 & 96.35 \\
\hline 19S/45E $9 \mathrm{dbb}$ & BLM North Harper Well & $\begin{array}{l}\text { Unused stock well near } \\
\text { center of KGRA. One of } \\
\text { few wells in the area }\end{array}$ & -- & -- & 695 & $>500$ \\
\hline $19 \mathrm{~S} / 45 \mathrm{E} 28 \mathrm{acb}$ & BLM Page Well & $\begin{array}{l}\text { Unused stock well } 1.5 \\
\text { miles west of the KGRA. } \\
\text { One of few wells in the } \\
\text { area. }\end{array}$ & "warm"1 & -- & 622 & 463.60 \\
\hline 19S/45E 36aad & County Landfill Well & $\begin{array}{l}\text { Industrial well in south- } \\
\text { ern part of KGRA. Only } \\
\text { operating well in southern } \\
\text { part of the KGRA }\end{array}$ & -- & -- & 310 & 175.26 \\
\hline $19 \mathrm{~S} / 46 \mathrm{E} 4 \mathrm{dac}$ & Rodger Finley Well & $\begin{array}{l}\text { Domestic well } 3 \text { miles } \\
\text { east of the Vale KGRA }\end{array}$ & 79 & 767 & 575 & ${ }^{1} 400$ \\
\hline $19 \mathrm{~S} / 46 \mathrm{E} 18 \mathrm{dbb}$ & Martin Sayers Well & $\begin{array}{l}\text { Stock well of unknown } \\
\text { depth and temperature one } \\
\text { half mile east of the } \\
\text { KGRA. One of few wells } \\
\text { in this area. Should be } \\
\text { sampled and evaluated }\end{array}$ & -- & -- & -- & 490.12 \\
\hline 19S/46E $21 \mathrm{bac}$ & Beef Northwest Well & $\begin{array}{l}\text { Stock well } 1.5 \text { miles east } \\
\text { of the KGRA }\end{array}$ & 77 & 1,005 & 865 & 1360 \\
\hline 20S/45E $5 \mathrm{cab}$ & Russell Land Co. Well & $\begin{array}{l}\text { Stock well } 1.5 \text { miles west } \\
\text { of the southern KGRA. } \\
\text { One of few wells in the } \\
\text { area }\end{array}$ & -- & -- & 320 & -- \\
\hline
\end{tabular}


Table 1. Description of and preliminary data from proposed monitoring sites in the vicinity of the Vale, Oregon, geothermal area-Continued

$\left[^{\circ} \mathrm{F}\right.$, degrees Fahrenheit; $\mu / \mathrm{cm}$, microsiemens per centimeter at $25^{\circ}$ Celsius; psi, pounds per square inch; --, no data;

KGRA, Known Geothermal Resource Area; BLM, Bureau of Land Management; >, greater than; NA, not applicable]

\begin{tabular}{|c|c|c|c|c|c|c|}
\hline Location & Name of Feature & Description & $\begin{array}{c}\text { Temperature } \\
\left({ }^{\circ} \mathrm{F}\right)\end{array}$ & $\begin{array}{c}\text { Specific } \\
\text { conductance } \\
(\mu / \mathrm{cm})\end{array}$ & $\begin{array}{l}\text { Depth } \\
\text { of well } \\
\text { (feet) }\end{array}$ & $\begin{array}{l}\text { Depth to } \\
\text { water (feet } \\
\text { below land } \\
\text { surface) }\end{array}$ \\
\hline 20S/45E $21 \mathrm{ddc}$ & Chalk Spring & $\begin{array}{l}\text { Nonthermal spring } 2 \text { miles } \\
\text { south of the KGRA. One } \\
\text { of the only hydrologic } \\
\text { features in the area }\end{array}$ & 70 & 817 & NA & NA \\
\hline 20S/45E 23cdd & Magnas Ekangar Well & $\begin{array}{l}68 \text { degree irrigation well } \\
2 \text { miles south of the } \\
\text { KGRA }\end{array}$ & ${ }^{1} 71$ & -- & 256 & ${ }^{1} 100$ \\
\hline 20S/45E 29bbd & Mud Spring & $\begin{array}{l}\text { Nonthermal spring } 3 \text { miles } \\
\text { southwest of the KGRA. } \\
\text { One of the only hydro- } \\
\text { logic features in the area }\end{array}$ & $67-70$ & $307-322$ & NA & NA \\
\hline $21 \mathrm{~S} / 45 \mathrm{E} 12 \mathrm{aad}$ & $\begin{array}{l}\text { Mitchell Butte } \\
\text { Hot Spring }\end{array}$ & $\begin{array}{l}\text { Hot spring } 5 \text { miles south } \\
\text { of the KGRA. The closest } \\
\text { geothermal feature outside } \\
\text { of the KGRA }\end{array}$ & $134-143$ & 556 & NA & NA \\
\hline
\end{tabular}

${ }_{1}^{1}$ Data from water well reports.

2 Data from Gannett (1988).

The nearest geothermal features outside of the KGRA are 5 to 7 miles to the south along the Owyhee River. These include Mitchell Butte Hot Spring, Snively Hot Spring, the unnamed hot spring in T21S/R45E sec. 14, informally referred to as Siphon Hot Spring, and the shallow hot well at the ethanol plant in T21S/ $\mathrm{R} 45 \mathrm{E}$ sec. 13. The nature of the connection (if any) of these distant thermal springs to the geothermal system at Vale is not known. Given this uncertainty, some monitoring of these features is deemed appropriate. Because of its proximity to the Vale KGRA, Mitchell Butte Hot Spring (table 3) was chosen for monitoring.

There are a number of water wells around the KGRA that produce 70 to $90^{\circ} \mathrm{F}$ water from aquifers in the Tertiary sedimentary rocks (table 2). Many of these wells lie east of the heat-flow anomaly, and the water they produce may include some component of outflow from the geothermal system; therefore, some of these wells have been selected for monitoring. Evaluating the geochemistry of water from these wells may help determine the nature of any connection.

No wells are known to produce thermal water from aquifers in the shallow Quaternary alluvial gravels that cover the valley floors in the area.
Gannett (1990) showed that the source of recharge to the shallow alluvial gravel is predominantly a combination of irrigation canal leakage and deep percolation of irrigation water applied to fields. It is possible, however, that thermal water upwelling from underlying Tertiary sediments may be locally providing some recharge to shallow gravel aquifers. Although there are no anomalous temperatures reported in wells producing from the shallow gravel, elevated arsenic concentrations in some shallow wells in the Vale area suggest some localized contribution of thermal water to this aquifer. Because of this, some wells in the shallow alluvial aquifer in the vicinity of the KGRA should be monitored. Specific wells were not identified in this reconnaissance study.

Two nonthermal springs located south of the KGRA were selected for monitoring (table 3). These springs are the only features available in that area, and they may provide information on the chemistry of nonthermal ground water in the area and possibly on the isotopic composition of local precipitation. 
Table 2. Data from selected wells in the vicinity of the Vale, Oregon, geothermal area

[Primary use codes: D, domestic; G, geothermal; I, irrigation; IN, industrial; S, stock; U, unused. NA, not available]

\begin{tabular}{|c|c|c|c|c|c|c|c|c|c|c|c|}
\hline Location & Owner & $\begin{array}{c}\text { Date } \\
\text { constructed }\end{array}$ & Latitude & Longitude & $\begin{array}{c}\text { Altitude } \\
\text { of land } \\
\text { surface } \\
\text { (feet) }\end{array}$ & $\begin{array}{c}\text { Depth of } \\
\text { well } \\
\text { (feet) }\end{array}$ & $\begin{array}{l}\text { Depth } \\
\text { of casing } \\
\text { or liner } \\
\text { (feet) }\end{array}$ & $\begin{array}{c}\text { Diameter } \\
\text { of casing } \\
\text { or line } \\
\text { (inches) }\end{array}$ & $\begin{array}{c}\text { Open } \\
\text { interval }\end{array}$ & $\begin{array}{c}\text { Primary } \\
\text { use of } \\
\text { well }\end{array}$ & $\begin{array}{c}\text { Reported } \\
\text { yield } \\
\text { (gallons } \\
\text { per minute) }\end{array}$ \\
\hline $18 \mathrm{~S} / 45 \mathrm{E} 18 \mathrm{ddb}$ & Charles Burden Well & $8 / 89$ & $43^{\circ} 59^{\prime} 56^{\prime \prime}$ & $117^{\circ} 14^{\prime} 52^{\prime \prime}$ & 2,370 & 260 & 260 & 4 & $160-260$ & $\mathrm{D}$ & 100 \\
\hline $18 \mathrm{~S} / 45 \mathrm{E} 20 \mathrm{dcd} 1$ & $\begin{array}{l}\text { Oregon Trail Mushroom } \\
\text { Company }\end{array}$ & $10 / 82$ & $43^{\circ} 58^{\prime} 57^{\prime \prime}$ & $117^{\circ} 13^{\prime} 50^{\prime \prime}$ & 2,250 & 125 & 40 & 12 & $40-125$ & G & 550 \\
\hline $18 \mathrm{~S} / 45 \mathrm{E} 20 \mathrm{dcd} 2$ & Robert Butler & $9 / 83$ & $43^{\circ} 58^{\prime} 57^{\prime \prime}$ & $117^{\circ} 13^{\prime} 52^{\prime \prime}$ & 2,250 & 140 & 39 & 8 & $39-140$ & $\mathrm{U}$ & 125 \\
\hline $18 \mathrm{~S} / 45 \mathrm{E} 28 \mathrm{abb}$ & Robert Butler & $8 / 79$ & $43^{\circ} 58^{\prime} 50^{\prime \prime}$ & $117^{\circ} 12^{\prime} 46^{\prime \prime}$ & 2,320 & 265 & 42 & 10 & $42-265$ & $\mathrm{D}$ & 12 \\
\hline 18S/45E 32aca & James Linville & 9/91 & $43^{\circ} 57^{\prime} 49^{\prime \prime}$ & $117^{\circ} 13^{\prime} 51^{\prime \prime}$ & 2,290 & 213 & 213 & 4 & $\begin{array}{l}143-153 \\
163-183\end{array}$ & $\mathrm{D}$ & 15 \\
\hline $18 \mathrm{~S} / 46 \mathrm{E} 31 \mathrm{adb}$ & Betty Wendt & $12 / 74$ & $43^{\circ} 57^{\prime} 49^{\prime \prime}$ & $117^{\circ} 07^{\prime} 43^{\prime \prime}$ & 2,490 & 887 & 60 & 16 & $60-887$ & I & 50 \\
\hline 18S/46E $31 \mathrm{ddd}$ & Betty Wendt & $4 / 75$ & $43^{\circ} 57^{\prime} 12^{\prime \prime}$ & $117^{\circ} 07^{\prime} 34^{\prime \prime}$ & 2,570 & 757 & 225 & 12 & $225-757$ & $\mathrm{U}$ & 800 \\
\hline 19S/44E 36cda & Russell Land Co. & $9 / 78$ & $43^{\circ} 52^{\prime} 09^{\prime \prime}$ & $117^{\circ} 16^{\prime} 32^{\prime \prime}$ & 2,580 & 400 & 40 & 10 & $40-400$ & S? & 300 \\
\hline 19S/45E $9 \mathrm{dbb}$ & Bureau of Land Management & NA & $43^{\circ} 55^{\prime} 52^{\prime \prime}$ & $117^{\circ} 12^{\prime} 49^{\prime \prime}$ & 2,820 & 695 & NA & 8 & NA & $\mathrm{U}$ & 7 \\
\hline $19 \mathrm{~S} / 45 \mathrm{E} 28 \mathrm{acb}$ & Bureau of Land Management & $9 / 67$ & $43^{\circ} 53^{\prime} 30^{\prime \prime}$ & $117^{\circ} 12^{\prime} 52^{\prime \prime}$ & 2,850 & 622 & 620 & & $540-620$ & $\mathrm{U}$ & 12 \\
\hline 19S/45E 36aad & Malheur County Landfill & $6 / 82$ & $43^{\circ} 52^{\prime} 41^{\prime \prime}$ & $117^{\circ} 08^{\prime} 43^{\prime \prime}$ & 2,550 & 310 & 119 & 6 & $113-310$ & IN & 50 \\
\hline 19S/46E 4dac & Rodger Finley & $8 / 79$ & $43^{\circ} 56^{\prime} 34^{\prime \prime}$ & $117^{\circ} 05^{\prime} 17^{\prime \prime}$ & 2,610 & 575 & 205 & 8 & $205-575$ & $\mathrm{D}$ & 15 \\
\hline 19S/46E $18 \mathrm{dbb}$ & Martin Sayers & 1920 's & $43^{\circ} 55^{\prime} 01^{\prime \prime}$ & $117^{\circ} 08^{\prime} 00^{\prime \prime}$ & 2,780 & NA & NA & NA & NA & S & NA \\
\hline 19S/46E $21 \mathrm{bac}$ & Beef Northwest & $12 / 89$ & $43^{\circ} 54^{\prime} 23^{\prime \prime}$ & $117^{\circ} 05^{\prime} 53^{\prime \prime}$ & 2,640 & 865 & 617 & 12 & $\begin{array}{l}360-420 \\
460-480 \\
560-580\end{array}$ & S & 400 \\
\hline 20S/45E $5 \mathrm{cab}$ & Russell Land Co. & $1958 ?$ & $43^{\circ} 51^{\prime} 35^{\prime \prime}$ & $117^{\circ} 14^{\prime} 54^{\prime \prime}$ & 2,660 & 320 & 90 & NA & NA & S & NA \\
\hline 20S/45E $23 \mathrm{cdd}$ & Magnas Ekangar Well & $7 / 92$ & $43^{\circ} 48^{\prime} 35^{\prime \prime}$ & $117^{\circ} 11^{\prime} 12^{\prime \prime}$ & 2,540 & 256 & 90 & 12 & $70-90$ & I & 1,400 \\
\hline
\end{tabular}


Table 3. Data from selected springs in the vicinity of the Vale, Oregon, geothermal area [ ${ }^{\circ} \mathrm{F}$, degrees Fahrenheit]

\begin{tabular}{|c|c|c|c|c|c|c|c|}
\hline Location & Spring name & Latitude & Longitude & $\begin{array}{l}\text { Altitude } \\
\text { of land } \\
\text { surface } \\
\text { (feet) }\end{array}$ & $\begin{array}{l}\text { Discharge } \\
\text { (gallons } \\
\text { per } \\
\text { minute) }\end{array}$ & $\begin{array}{l}\text { Temperature } \\
\left({ }^{\circ} \mathrm{F}\right)\end{array}$ & Comments \\
\hline $20 \mathrm{~S} / 45 \mathrm{E} 21 \mathrm{ddc}$ & Chalk Spring & $43^{\circ} 48^{\prime} 40^{\prime \prime}$ & $117^{\circ} 13^{\prime} 05^{\prime \prime}$ & 2,735 & ${ }^{1} 0.1$ & 70 & $\begin{array}{l}\text { Spring modified for stock } \\
\text { watering, discharges from } \\
\text { pipe into trough }\end{array}$ \\
\hline 20S/45E 29bbd & Mud Spring & $43^{\circ} 48^{\prime} 25^{\prime \prime}$ & $117^{\circ} 15^{\prime} 02^{\prime \prime}$ & 3,060 & & 70 & $\begin{array}{l}\text { Diffuse discharge, may } \\
\text { be difficult to measure } \\
\text { flow rate }\end{array}$ \\
\hline 21S/45E 12aad & $\begin{array}{l}\text { Mitchell } \\
\text { Butte } \\
\text { Hot Spring }\end{array}$ & $43^{\circ} 45^{\prime} 47^{\prime \prime}$ & $117^{\circ} 09^{\prime} 20^{\prime \prime}$ & 2,270 & ${ }^{2} 16$ & 143 & $\begin{array}{l}\text { Discharges from multiple } \\
\text { orifices, flow measure- } \\
\text { ment will be difficult }\end{array}$ \\
\hline
\end{tabular}

1 Includes flow from pipe only, additional seepage occurs in streambed.

2 From Brown and others (1980).

To aid in differentiating development-related changes in the hydrologic system from natural changes due to climate, it would be desirable to monitor water levels in a few wells clearly outside of the influences of the geothermal system. Such wells would preferably be completed in bedrock units and located at least 10 to 15 miles from the KGRA. These wells also should be located away from the influence of any high-volume ground-water pumping. Suitable wells were not located as part of this project.

The chemical parameters for which monitoring is recommended are listed in Appendix 1. These parameters are, for the most part, those recommended in the "Guidelines for Acquiring Environmental Baseline Data on Federal Geothermal Leases," developed by the U.S. Department of the Interior Geothermal Environmental Advisory Panel (1977). The recommended parameters include the major ions and minor constituents commonly found in thermal and nonthermal waters, as well as selected trace elements. Limited stable isotope data also should be collected to help characterize different types of water in the area. After the initial sampling periods and evaluation of the data, a smaller number of parameters may be selected for long-term monitoring. Temperature/depth profiles should be measured periodically in wells intersecting thermal aquifers. All sampling and data collection should be conducted according to U.S. Geological Survey standards and protocols, paying particular attention to special requirements for thermal waters.
Meteorological data must be available in order to assess trends in hydrologic data. A long-term weather station is operated about 10 miles east of Vale at the Oregon State University Malheur [Agricultural] Experiment Station. Data from this weather station should suffice for the Vale KGRA; however, the list of parameters collected at this station should be checked for completeness when hydrologic monitoring begins.

\section{Monitoring Schedule}

The primary objective of hydrologic monitoring in the Vale geothermal area is to detect any effects that development of the geothermal system might have on the hot spring in the area, on the existing geothermal users in the hot-spring area near Vale, and on users of domestic and irrigation wells that may have an indirect connection to the geothermal system. To recognize effects of development, it is necessary to have a firm understanding of the range of variations and long-term trends in the monitored parameters prior to development. Data presented by Gannett (1988) show both seasonal variability and long-term trends in water levels in the hot-spring area. Previous data collected from other thermal features near the Vale geothermal area have not been analyzed, and the variation in data collection techniques may make comparisons problematic. 
The proposed quarterly data collection schedule is designed to provide information on seasonal variability as well as on long-term trends (table 4). Data collection can be less frequent if no seasonal variations are observed, or they are characterized to the point where annual or semiannual monitoring is sufficient.

Well operation must be taken into consideration when scheduling water-level measurements or sampling. Water-level measurements are best taken when the well has been idle for some period of time. In contrast, wells must be pumping to obtain water samples. Domestic, stock, irrigation, and industrial wells were selected for sampling. The pumps of most domestic wells and many stock wells can be operated to obtain water samples at any time. Some stock wells may have the pump motors or generators removed during the winter.
The pumping rates of stock and domestic wells are low and pumping is discontinuous, so residual drawdown effects are minimal and reasonable water levels can be obtained any time. Two of the wells proposed for monitoring are irrigation wells that are operated for only a few months each year. It may be impractical to sample these wells outside of the regular irrigation season because of electrical demand charges. Conversely, water levels may be questionable during the irrigation season due to residual drawdown effects.

Two of the wells selected, the North Harper Well and the Page Well, are unused stock wells on BLM land. These are considered critical as they are the only wells in or near the central part of the KGRA. In order to sample these wells, it will be necessary to install pumps. Installation of permanent dedicated sampling pumps in these wells would be desirable.

Table 4. Measurement and sampling schedule for monitoring in the Vale, Oregon, geothermal area

[Frequency of measurement or sample collection: Q, quarterly; S, semiannually; A, annually; *, measurement or sampling will be done if well can be pumped; --, measurement or sample not applicable or practicable]

\begin{tabular}{|c|c|c|c|c|c|}
\hline Location & Name of feature & $\begin{array}{l}\text { Water } \\
\text { level }\end{array}$ & $\begin{array}{l}\text { Temperature } \\
\text { conductance }\end{array}$ & Discharge & $\begin{array}{c}\text { Chemical } \\
\text { sample }\end{array}$ \\
\hline $18 \mathrm{~S} / 45 \mathrm{E} 18 \mathrm{ddb}$ & Charles Burden Well & Q & Q & -- & A \\
\hline $18 \mathrm{~S} / 45 \mathrm{E} 20 \mathrm{dcd} 1$ & $\begin{array}{l}\text { Oregon Trail Mushroom } \\
\text { Company Production Well } \\
\text { (Hammond Well \#1) }\end{array}$ & -- & Q & -- & A \\
\hline $18 \mathrm{~S} / 45 \mathrm{E} 20 \mathrm{dcd} 2$ & $\begin{array}{l}\text { Robert Butler Geothermal } \\
\text { Test Well \#2 }\end{array}$ & Q & -- & -- & -- \\
\hline $18 \mathrm{~S} / 45 \mathrm{E} 28 \mathrm{abb}$ & Robert Butler Well & Q & Q & -- & A \\
\hline 18S/45E 32aca & James Linville Well & Q & Q & -- & A \\
\hline $18 \mathrm{~S} / 46 \mathrm{E} 31 \mathrm{adb}$ & Betty Wendt Well & -- & -- & -- & A \\
\hline 18S/46E 31ddd & Betty Wendt Well & Q & -- & -- & -- \\
\hline 19S/44E 36cda & Russell Land Co. Well & Q & $S^{*}$ & -- & A \\
\hline 19S/45E $9 \mathrm{dbb}$ & BLM North Harper Well & Q & Q & -- & $S$ \\
\hline $19 \mathrm{~S} / 45 \mathrm{E} 28 \mathrm{acb}$ & BLM Page Well & Q & Q & -- & $S$ \\
\hline 19S/45E 36aad & County Landfill Well & Q & Q & -- & S \\
\hline 19S/46E 4dac & Rodger Finley Well & Q & Q & -- & A \\
\hline $19 \mathrm{~S} / 46 \mathrm{E} 18 \mathrm{dbb}$ & Martin Sayers Well & Q & $S^{*}$ & -- & A \\
\hline 19S/46E $21 \mathrm{bac}$ & Beef Northwest Well & Q & Q & -- & $\mathrm{A} / \mathrm{S}$ \\
\hline 20S/45E $5 \mathrm{cab}$ & Russell Land Co. Well & Q & $S^{*}$ & -- & A \\
\hline 20S/45E $21 \mathrm{ddc}$ & Chalk Spring & -- & Q & Q & $\mathrm{A} / \mathrm{S}$ \\
\hline 20S/45E 23cdd & Magnas Ekangar Well & Q & $\mathrm{Q}^{*}$ & -- & $\mathrm{A} / \mathrm{S}$ \\
\hline 20S/45E 29bbd & Mud Spring & -- & Q & Q & $\mathrm{A} / \mathrm{S}$ \\
\hline 21S/45E 12aad & Mitchell Butte Hot Spring & -- & Q & Q & Q \\
\hline
\end{tabular}




\section{REFERENCES CITED}

Blackwell, D.D., Hull, D.A., Bowen, R.G., and Steele, J.L., 1978, Heat flow of Oregon: Oregon Department of Geology and Mineral Industries Special Paper 4, $42 \mathrm{p}$.

Bowen, R.G., and Blackwell, D.D., 1975, The Cow Hollow geothermal anomaly, Malheur County, Oregon: The Ore Bin, v. 37, no. 7, p. 109-121.

Brown, D.E., McLean, G.D., and Black, G.L., 1980, Preliminary geology and geothermal resource potential of the western Snake River Plain, Oregon: Oregon Department of Geology and Mineral Industries Open-File Report O-80-5, 114 p.

Brown, D.E., 1982, Map showing geology and geothermal resources of the Vale East 7 1/2' quadrangle, Oregon: Oregon Department of Geology and Mineral Industries, Geologic Map Series GMS 21, 1 sheet.

Farrar, C.D., Sorey, M.L., Rojstaczer, S.A., Janik, C.J., Mariner, R.H., Winnett, T.L., and Clark, M.D., 1985, Hydrologic and geochemical monitoring in Long Valley Caldera, Mono County, California, 1982-1984: U. S. Geological Survey WaterResources Investigations Report 85-4183, 127 p.
Ferns, M.L., and Urbanczyk, K.M., 1990, Geology and mineral resources of the Mitchell Butte Quadrangle, Malheur County, Oregon: Oregon Department of Geology and Mineral Industries, Geologic Map Series GMS 61, 1 sheet.

Gannett, M.W., 1988, Hydrogeologic assessment of the developed geothermal aquifer near Vale, Oregon: Oregon Water Resources Department Ground Water Open-File Report No. 88-04, 33 p.

Gannett, M.W., 1990, Hydrogeology of the Ontario area, Malheur County, Oregon: Oregon Water Resources Department Ground Water Report No. 34, 39 p.

Ingebritsen, S.E., Sherrod, D.R., and Mariner, R.H., 1989, Heat flow and hydrothermal circulation in the Cascade Range, north-central Oregon: Science, v. 243, p. 1458-1462.

Norton, D.R., and Friedman, Irving, 1985, Chloride flux out of Yellowstone National Park: Journal of Volcanology and Geothermal Research, v. 26, p. 231-250.

U.S. Department of the Interior, 1977, Guidelines for acquiring environmental baseline data on Federal geothermal leases: Menlo Park, California, The Geothermal Environmental Advisory Panel, 26 p. 


\section{APPENDIX 1}

Physical parameters, chemical constituents and isotopes for monitoring sites (includes analytical methods and detection limits for laboratory analyses).

\section{A. Field parameters}

1. $\mathrm{pH}$, alkalinity, temperature, conductivity

2. dissolved oxygen, when feasible (for instance, dissolved oxygen is not meaningful when samples are obtained from wells equipped with air-jet pumps)

B. Major chemistry (dissolved unless otherwise stated) and physical parameters (concentration or unit values listed by each parameter are the minimum detection levels that will be used)

\section{Major ions:}

$\mathrm{Ca}$, atomic absorption, $0.1 \mathrm{mg} / \mathrm{L}$

$\mathrm{Mg}$, atomic absorption, $0.1 \mathrm{mg} / \mathrm{L}$

$\mathrm{Na}$, atomic absorption, $0.1 \mathrm{mg} / \mathrm{L}$

$\mathrm{K}$, atomic absorption, $0.1 \mathrm{mg} / \mathrm{L}$

$\mathrm{HCO}_{3}$, titration, $1 \mathrm{mg} / \mathrm{L}$

$\mathrm{C} 1$, ion chromatography, $1 \mathrm{mg} / \mathrm{L}$

$\mathrm{SO}_{4}$, ion chromatography, $1 \mathrm{mg} / \mathrm{L}$

F, ion chromatography, $10 \mu \mathrm{g} / \mathrm{L}$

2. Minor constituents:

$\mathrm{SiO}_{2}$, colorimetry, molybdate blue, $0.1 \mathrm{mg} / \mathrm{L}$

A1, atomic emission, DG plasma, $10 \mu \mathrm{g} / \mathrm{L}$

$\mathrm{Fe}$, atomic absorption, $10 \mu \mathrm{g} / \mathrm{L}$

$\mathrm{Mn}$, atomic absorption, $10 \mu \mathrm{g} / \mathrm{L}$

3. Nutrients:

total P, colorimetry, $10 \mu \mathrm{g} / \mathrm{L}$

ortho P, colorimetry, $10 \mu \mathrm{g} / \mathrm{L}$

$\mathrm{NO}_{2}+\mathrm{NO}_{3}$, colorimetry, $0.1 \mathrm{mg} / \mathrm{L}$

$\mathrm{NH}_{4}$, colorimetry, $0.01 \mathrm{mg} / \mathrm{L}$

4. Dissolved solids, residue on evaporation, $1 \mathrm{mg} / \mathrm{L}$

5. Turbidity, nephelometry, 0.1 NTU
C. Isotopes (dissolved):

1. oxygen-18/oxygen-16, mass spectrometry, $+/-0.15 \mathrm{o} / \mathrm{oo}$

2. deuterium/protium, mass spectrometry, $+/-1.5 \mathrm{o} / \mathrm{oo}$

D. Trace elements (dissolved):

1. As, atomic absorption, $1 \mu \mathrm{g} / \mathrm{L}$

2. Ag, atomic absorption, graphite furnace, $1 \mu \mathrm{g} / \mathrm{L}$

3. B, atomic emission, DC plasma, $10 \mu \mathrm{g} / \mathrm{L}$

4. Ba, atomic absorption, $100 \mu \mathrm{g} / \mathrm{L}$

5. Cd, atomic absorption, $10 \mu \mathrm{g} / \mathrm{L}$

6. Cr, DC plasma, $1 \mu \mathrm{g} / \mathrm{L}$

7. $\mathrm{Cu}$, atomic absorption, $10 \mu \mathrm{g} / \mathrm{L}$

8. Hg, atomic absorption, flameless, $0.1 \mu \mathrm{g} / \mathrm{L}$

9. $\mathrm{Li}$, atomic absorption, $10 \mu \mathrm{g} / \mathrm{L}$

10. Mo, atomic absorption, $1 \mu \mathrm{g} / \mathrm{L}$

11. $\mathrm{Pb}$, atomic absorption, graphite furnace, $1 \mu \mathrm{g} / \mathrm{L}$

12. Se, atomic absorption, $1 \mu \mathrm{g} / \mathrm{L}$

13. Sr, atomic absorption, $10 \mu \mathrm{g} / \mathrm{L}$

14. Zn, atomic absorption, $10 \mu \mathrm{g} / \mathrm{L}$

E. Dissolved gases

1. $\mathrm{CO}_{2}$, calibrated from alkalinity tritration

2. $\mathrm{H}_{2} \mathrm{~S}$, calculated from total recoverable sulfide; total recoverable sulfide determined by iodometric titrimetry with detection limit of $0.5 \mathrm{mg} / \mathrm{L}$ as $\mathrm{S}$

3. $\mathrm{NH}_{3}$, calculated from ammonium ion concentration

F. Radon-222 (dissolved), liquid scintillation, 70 pCi/L

G. Gross radioactivity (dissolved):

gross alpha, residue proc., $0.4 \mu \mathrm{g} / \mathrm{L}(\mathrm{U})$, $0.4 \mathrm{pCi} / \mathrm{L}$ (Th-230)

gross beta, residue proc., $0.4 \mathrm{pCi} / \mathrm{L}$ (Sr-90/Y-90, Cs-137)

H. Vertical temperature profiles in wells 